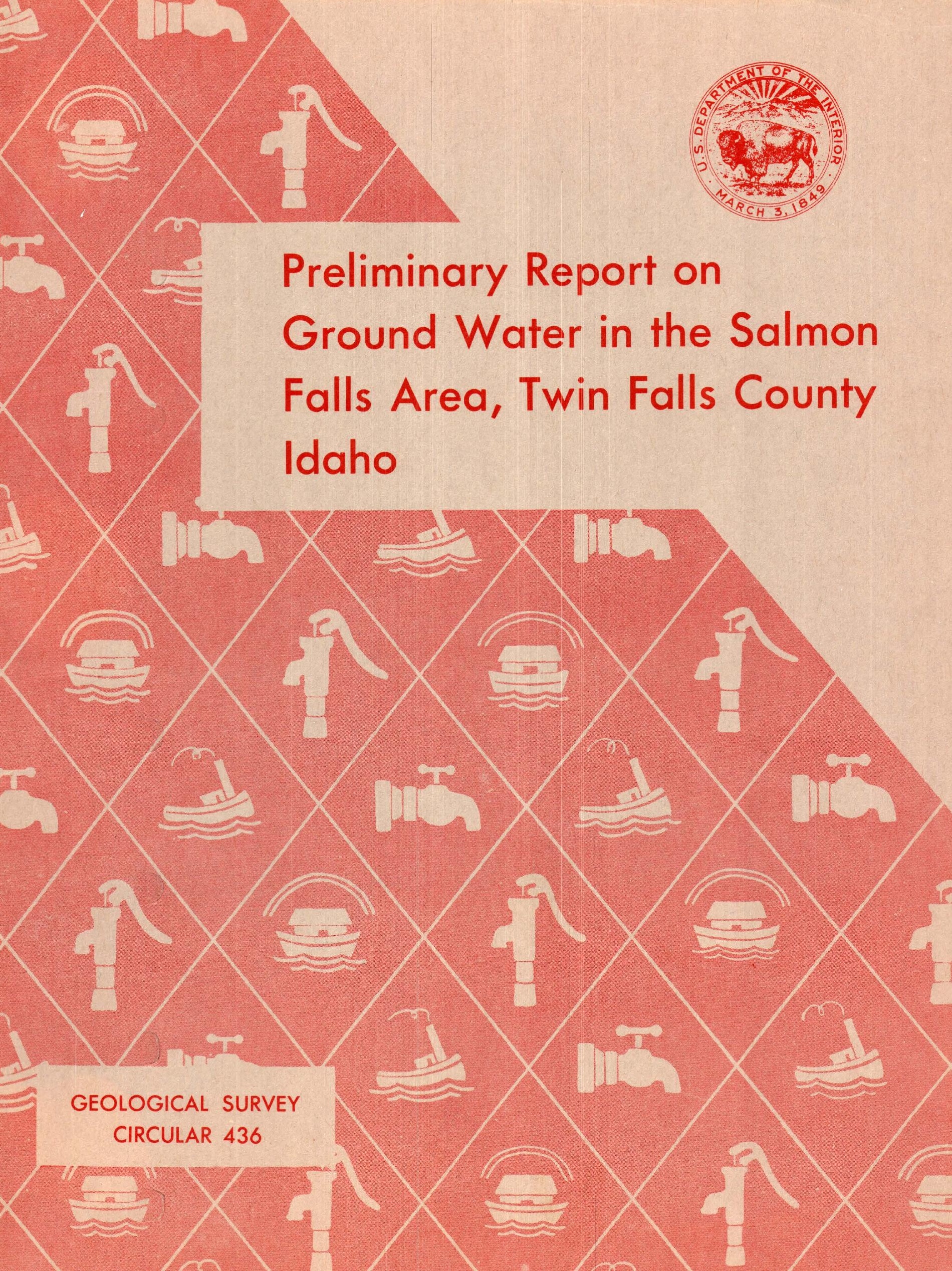




\section{Preliminary Report on Ground Water in the Salmon Falls Area, Twin Falls County, Idaho}

By K. H. Fowler

父

Prepared in cooperation with the U.S. Bureau of Reclamation

GEOLOGICAL SURVEY CIRCULAR 436 
United States Department of the Interior STEW ART L. UDALL, SBCrBTARY

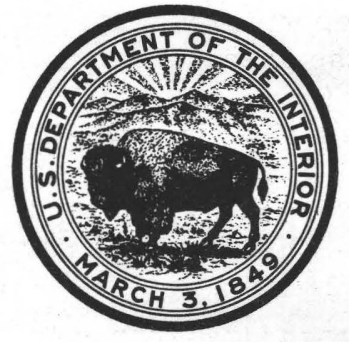

Geological Survey

THOMAS B. NOLAN, DiRBCTOR

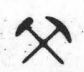

Free on application to the U.S. Geological Survey, Washington 25, D. C. 


\section{CONTENTS}

Page

Abstract.

(1)

Purpose and scope of report

Purpose and scope of report....-.-

Acknowledgments...-

Well-numbering system

Geographic setting.....................

Surface features and drainage......-

Climate

Land use and agricultural development

Geologic formations and their water-

bearing character

Younger alluvium and windblown

deposits

Snake River basalt

Older alluvium

Silicic volcanic rocks . . . . . . . . .
Page

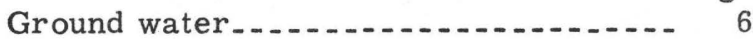

Source and occurrence _........... 6

Development and utilization........ 8

Amount of recharge ............ 8

Recharge from direct

precipitation ............... 9

Recharge from upland to the east and southeast............... 9

Recharge from reservoir losses..- 10

Seepage loss from canals ........ 10

Percolation from irrigation ....... 11

Potential supply ................. 12

Quality of water..... 12

Conclusions ....................... 16

References....................... 17

ILLUSTRATIONS

Plate 1. Map of Salmon Falls area showing location of wells and generalized water

table contours. . . . . .

Figure 1. Map showing Salmon Falls area

2. Sketch showing well-numbering system _...

3. Isohyetal map of Salmon Falls Creek area and Salmon Falls Creek basin _..... 4

4. Classification of water for irrigation, Salmon Falls area.

\section{TABLES}

Table 1. Data from pumping tests of wells in Salmon Falls area $1-c_{9}$

2. Estimated average annual recharge to aquifers in the Salmon Falls area._..... 11

3. Chemical analyses of water in Salmon Falls area 


\title{
Preliminary Report on Ground Water in the Salmon Falls Area, Twin Falls County, Idaho
}

\author{
By K. H. Fowler
}

\begin{abstract}
The Salmon Falls area contains about 80,000 acres of irrigable land, of which about 30,000 acres receives some water from the distribution system of Salmon River Canal Co., Ltd. This system utilizes virtually all the available surface water.

A substantial amount of surface water, estimated to be about 70,000 acre-feet annually, is lost by leakage from the reservoir and the distribution system. Some of this water could be salvaged by lining sections of the canal where excessive losses occur.

Ground water has not been extensively developed in the area, but some successful irrigation wells furnished supplemental irrigation water. Recharge to the area is from precipitation on the area, seepage from peripheral streams, seepage losses from the reservoir and canal system, irrigation seepage, and ground-water underflow.
\end{abstract}

Ground water leaves the area by underflow to the north and northwest, and eventually rèach es the Snake River. The total amount of underflow from the area was estimated by three different methods to be $17,000,100,000$, and 170,000 acrefeet per year. The preliminary estimate of 100,000 acre-feet was derived by the inventory of recharge and is probably more accurate than the other two methods.

Calculations, based on estimates of transmissibility computed from specific capacities of wells, suggest that there may be some channels or conduits of higher than average transmissibility through which a large part of the underflow leaves the area. Possibly 25 percent of the ground-water outflow could be intercepted by wells. However, in part of the area the depth to water may be excessive for economic development.

Chemical analyses of 25 samples of ground water indicate that most of the water sampled is suitable for irrigation. The samples found least suitable were of water occurring at shallow depth, south and east of Hollister.

\section{INTRODUCTION}

PURPOSE AND SCOPE OF REPORT

There are about 80,000 acres of irrigable land in the south-central part of Twin Falls County, Idaho, of which about 50,000 is largely undeveloped. Most of this land was included in the original project of the Salmon River Canal Co. A small part of the acreage is at a higher elevation than the surface-water supply for the project. Owing to insufficient runoff in Salmon Falls Creek and to water losses from the reservoir and canals, the acreage in the project has been reduced until as of 1959 only about 30,000 acres received water through the distribution system. Some of the irrigated land receives an insufficient water supply for full economic development. To supplement the present water supply and to supply additional land, more water is needed than is available from surface-water sources within the area.

This investigation was made to estimate the amount, availability, source, and direction of movement of ground water in the area, to establish whether the ground-water body is tributary to the Snake River, and to consider the possibility of its use to supplement the surface-water supply for irrigation in the area. It was made in cooperation with the U.S. Bureau of Reclamation as part of their comprehensive study and evaluation of undeveloped land and water resources of the upper and middle Snake River basin.

The canvassing of all wells in the area was completed in the spring of 1957 and depth-towater measurements were made in 71 wells. The altitude of the measuring points at about 75 wells was established by third-order spirit leveling by the U.S. Bureau of Reclamation. A few altitudes were established by altimeter surveys, and locally, where more exact data were not available, reported depths to water from canal company records and altitudes interpolated from topographic maps (corrected to sea-level datum) furnished by the canal company were used. The location of wells are shown on plate 1. Records of wells canvassed are given in a separate report (Fowler, 1960). Geologic information was interpreted from logs of wells furnished by drillers and well owners, supplemented by a reconnaissance of the area by the author. 


\section{LOCATION AND EXTENT OF THE AREA}

The Salmon Falls area is on the Snake River Plain in Twin Falls County, Idaho. It includes all or parts of Ts. 10-14 S., Rs. 14-17 E., of the Boise base line and meridian (fig. 1). It is bordered by Salmon Falls Creek on the west and by the Rock Creek Hills (also known as the South Hills and as the Cassia Mountains) on the east and southeast. The northern boundary is arbitrarily defined at the High Line Canal of the Twin Falls Canal Co.

\section{ACKNOWLEDGMENTS}

Residents and land owners of the area allowed access to their wells and furnished much useful information. Well drillers who cooperated by furnishing logs or other infor- mation and helped to locate many wells include Gray Brothers, Ora Jones, R. T. McClure, Harry Moore, Jim Moore, and W. T. Williams.

The Salmon River Canal Co., Ltd., H. M. Griffith, manager, furnished maps and other information from company files. The occasional use of company office space also facilitated the investigation. The Layne and Bowler Pump Co. at Twin Falls furnished pump-test data on wells tested by them.

\section{WELL-NUMBERING SYSTEM}

The well-numbering system used in Idaho by the U.S. Geological Survey indicates the location of wells within the official rectangular subdivisions of the public lands, with reference to the Boise base line and meridian

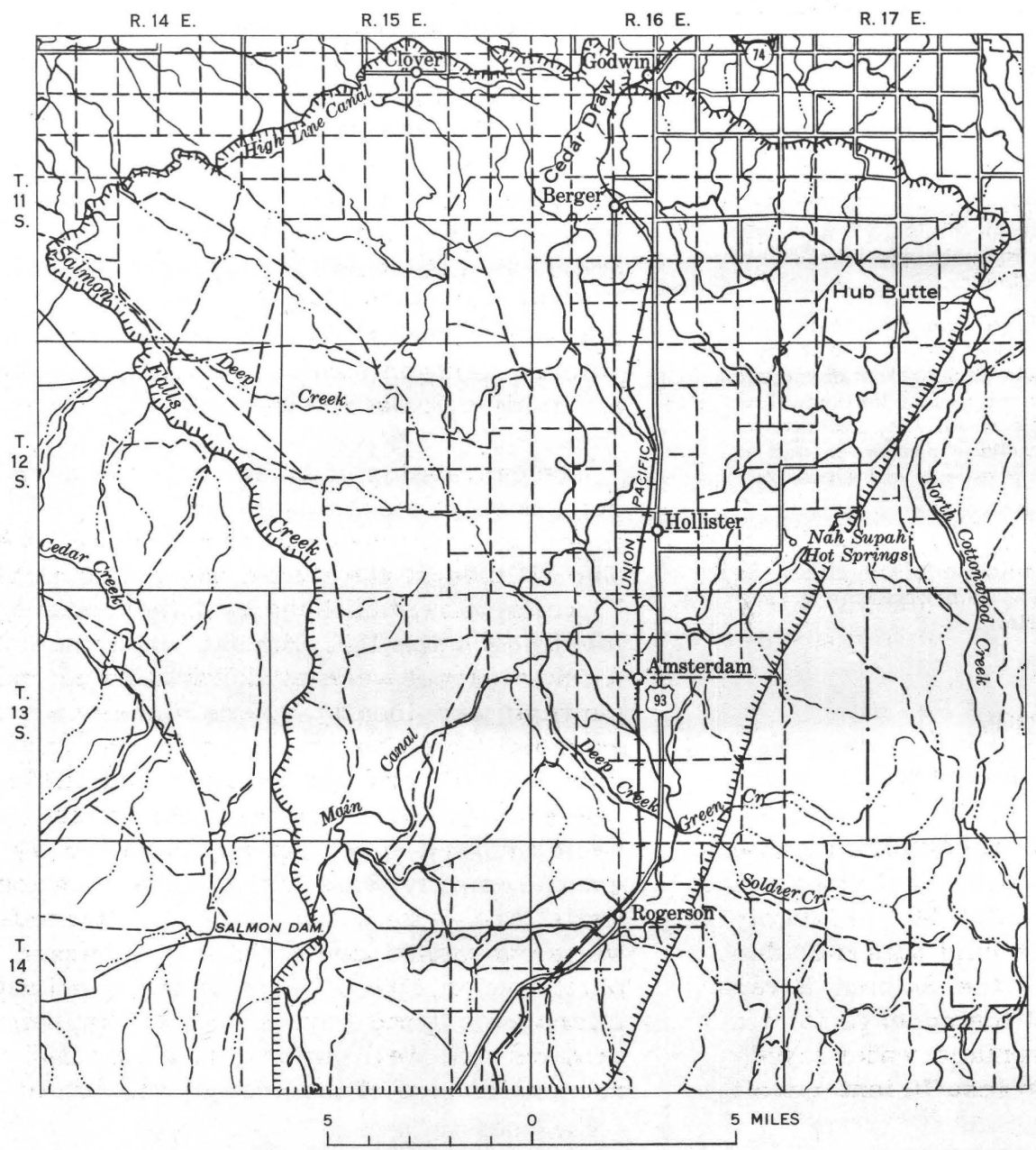

\section{EXPLANATION}

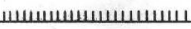
Boundary of Salmon Falls Creek area

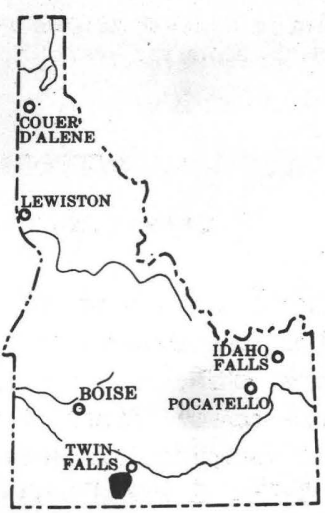

INDEX MAP OF IDAHO 

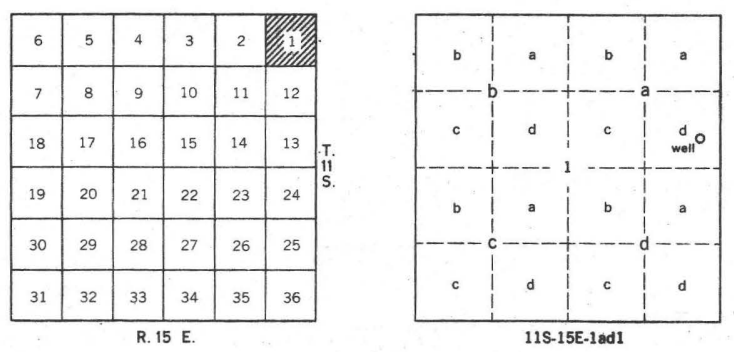

Figure 2-Sketch showing well-numbering system.

(fig. 2). The first two segments of a well number designate the township and range. The third segment gives the section number, followed by two letters and a numeral, which indicate, in order, the quarter section, the 40-acre tract, and the serial number of the well within the tract. Quarter sections are lettered a, b, c, and d in counterclockwise order, beginning with the northeast quarter of the section. Within the quarter sections, 40 -acre tracts are lettered in the same manner. Well 11S-15E-1ad1, for example, is in the $\mathrm{SE}^{1 / 4 \mathrm{NE}^{1 / 4}}$ sec. 1 , T. 11 S., R. $15 \mathrm{E}$., and is the first well visited in that 40 -acre tract.

\section{GEOGRAPHIC SETTING}

\section{SURFACE FEATURES AND DRAINAGE}

The land surface of the Salmon Falls area is a gently rolling plain which slopes generally northward toward the Snake River. Altitudes range from about 5,200 feet above mean sea level in the southern part of the area to about 4,100 feet at the northern end near the High Line Canal of the Twin Falls Canal Co. The surface of the plain is broken by shallow drainage ways and by small volcanic hills which rise a few hundred feet above the general land surface.

Salmon Falls Creek, which forms the western boundary of the area, has cut a deep narrow canyon as much as 400 feet below the general surface of the plain. It is the only perennial stream in the area and is the principal source of surface water for irrigation. Desert Creek and Deep Creek are ephemeral streams which cross the area in a northerly direction and are tributary to the Snake River. Several small ephemeral streams flow onto the area from the Rock Creek Hills which adjoin the area on the east, but their flow is so small that their channels are not well defined and at many places have been completely obliterated by cultivation. They are tributary to Deep Creek and Desert Creek.

\section{Climate}

The climate of the Salmon Falls area, like most of the Snake River Plain, is semiarid, being warm in summer and moderately cold in winter. The mean annual precipitation at Hollister is 9.35 inches, of which about 20 percent falls during the growing season from April to October. The precipitation at higher elevations in the Rock Creek Hills and in the upper part of the Salmon Falls Creek basin in Nevada is considerably. greater. It is estimated that the average annual precipitation on about 1,980 square miles of contributing drainage area is about 13 inches (fig. 3 ). The mean annual temperature at Hollister is $47.6^{\circ} \mathrm{F}$. The growing season is comparatively short and the irrigation season on the Salmon Falls project ranges from 80 to 130 days and averages about 110 .

\section{LAND USE AND AGRICULTURAL DEVELOPMENT}

About 30,000 acres is irrigated through the distribution system of the Salmon River Canal Co. A small area, less than 100 acres, in the southeast corner of the area is irrigated by surface water diverted from Deep Creek. Water from Cottonwood Creek is used to irrigate some lănd adjacent to the northeast corner of the area. Ground water pumped for irrigation is used mostly for supplementing the surface-water supply. The principal irrigated crops are alfalfa and clover, seed crops, beans, and peas. A few hundred acres, mostly at higher elevations near the Rock Creek Hills, produces grain without irrigation.

Most of the remaining 50,000 acres of irrigable land is uncultivated and is used only for grazing. Sagebrush and other desert plants are the predominant forms of vegetation, except in areas where the U.S. Bureau of Land Management has planted range grasses to improve the grazing value of the land.

The area is served by U.S. Highway 93 and a branch of the Union Pacific Railroad. 


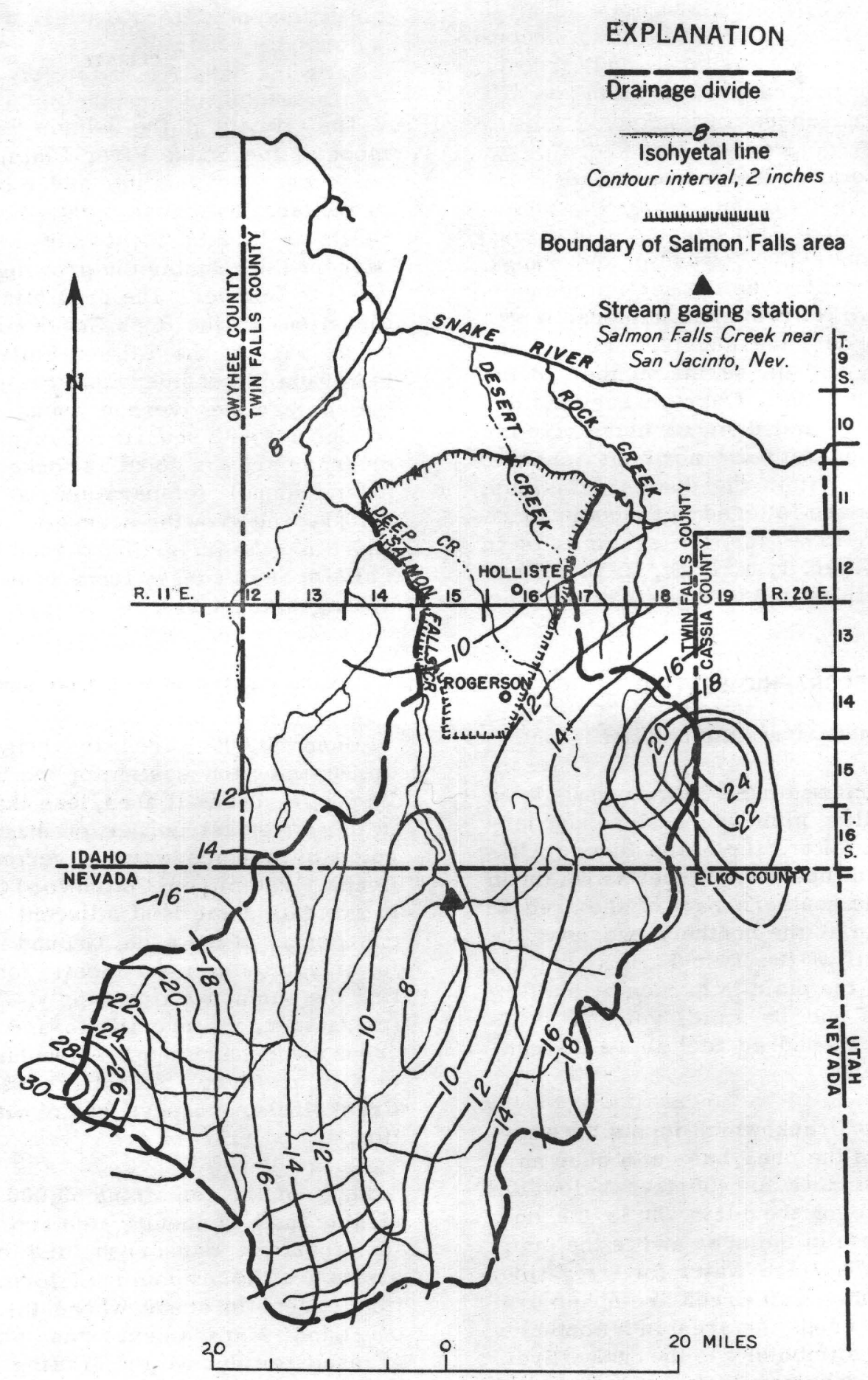

Figure 3. - Isohyetal map of Salmon Falls area and Salmon Falls Creek basin (U.S. Corps. of Engineers, 1952). 


\section{GEOLOGIC FORMATIONS AND THEIR WATER- BEARING CHARACTER}

The geology of the area was not studied in detail; however, logs of wells and a reconnaissance of surface features and exposed formations in the canyon of Salmon Falls Creek give the generalized geologic setting (pl. 1). The rocks consist of volcanic and sedimentary strata of various types which range from nearly impermeable to moderately permeable.

\section{YOUNGER ALLUVIUM AND WINDBLOWN DEPOSITS}

Alluvium and windblown deposits of Recent age mantle most of the area; however, they were not mapped in detail and, hence, are not indicated on plate 1 . The windblown deposits, which consist of fine sand and silt, range in thickness from a few inches to several feet. They are above the zone of saturation and therefore are not water bearing, but they transmit precipitation and unconsumed irrigation water to the underlying formations.

The alluvium in the broad flat portion of Deep Creek valley extends northwestward through the western part of the area; it contains some clay but consists mostly of sand and gravel composed of silicic volcanic rocks that were eroded from the hills to the east and southeast. The alluvium is moderately permeable, and in a small area southwest of Hollister where ground water occurs at shallow depth it yields water in sufficient quantity for domestic and stock supplies.

\section{SNAKE RIVER BASALT}

Most of the area is underlain by Snake River basalt of Pliocene to Recent age. The basalt consists of many flow sheets ranging in thickness from a few to several tens of feet. At some places the flow sheets are separated by lenses of windblown or water-laid sedimentary material. The weathered and eroded surfaces of some layers indicate that an appreciable length of time elapsed between extrusion of some of the flows. Much of the basalt is somewhat similar to the weathered Banbury basalt and other older basalt flows found at some places in the Snake River Plain, and appears to be considerably less permeable than most of the Snake River basalt.
Joints, fractures, and openings between successive flows, and lenses of permeable sediments between flows yield moderate to large quantities of water to wells where they are saturated. Between joints and interflow layers the basalt is relatively impermeable. On the whole, the transmissibility of the basalt aquifer in this area is much less than at most other places on the Snake River Plain. The size of the joints and the contact openings between flows become progressively smaller with depth so that where the depth to water is several hundred feet the basalt yields little water to wells. Most of the domestic, irrigation, and stock wells in the area produce water from the basalt or from the intercalated sediments, and at some places where the depth to water is moderate, their yield is adequate.

\section{OLDER ALLUVIUM}

Some wells in the area have been drilled through the Snake River basalt into sedimentary strata consisting of silt, clay, sand, and gravel of Pliocene(?) age (referred to in some driller's logs as "old lakebed deposits"). The strata are probably equivalent to the Idaho formation. This formation occurs in most places below the zone of saturation and thus is water bearing. It is the main source of water for several domestic, stock, and smaller irrigation wells, but because of its comparatively low permeability, it yields water in quantities too small for extensive irrigation use.

\section{SILICIC VOLCANIC BOCKS}

Silicic volcanic rocks of Tertiary age underlie the Snake River basalt and older alluvium throughout most of the area and are exposed at some places in the canyon of Salmon Falls Creek and in the Rock Creek Hills. They range from glassy to porphyritic in texture and from black to red and light gray in color, and are usually massiye. The rocks are commonly called rhyolite but they include much latite as well as other silicic volcanic rocks. The transmissibility of these rocks at most places is probably very low, but at some places the rocks contain jòints and other fractures which transmit moderate quantities of water. 
The deepest well in the area, $14 \mathrm{~S}-16 \mathrm{E}-$ $16 \mathrm{ba1}$, is 1,210 feet deep. The driller's log for the lowermost 304 feet shows silicic volcanic rocks intercalated with fine sediments or altered silicic rocks. According to the owner, the well was tested at several denths and no significant increase in yield was obtained after the well entered the silicic volcanic rocks. Unfortunately no record was kept of the tests, except for the final one which shows a specific capacity of $3.2 \mathrm{gpm}$ (gallons per minute) per foot of drawdown. In another part of the area, well $13 \mathrm{~S}-17 \mathrm{E}-6 \mathrm{bc} 2$ is reported to be 600 feet deep and was drilled for almost the total depth in solid rock that is probably silicic volcanic rock. Water under artesian pressure was encountered in what was described as a crevice in the rock. The combined flow of this well and another one nearby reportedly was about $2,700 \mathrm{gpm}$. for a few years after they were drilled in 1903. Well 13S-15E-12bc1 also taps silicic volcanic rock. The yield of this well was increased 30 percent by drilling 100 feet into the silicic rock to a total depth of 550 feet. These data suggest that the silicic volcanic rocks have a wide range in yield; however, the silicic rock in many parts of the area has not been tested.

\section{GROUND WATER}

\section{SOURCE AND OCCURRENCE}

Ground water in the Salmon Falls area is derived from precipitation on the area, from seepage loss from streams, canals, and reservoirs, from percolation from irrigated tracts, and from ground-water underflow from adjoining areas to the south and east. In general the direction of ground-water movement is to the north and northwest toward the Snake River, which serves as a base level for ground water in all of southern Idaho. Much of the ground water enters the area from the Salmon River Canal Co. reservoir and from areas of higher elevation to the south and east. The general slope of the water table in parts of the area for which data are available is shown on plate 1 .

In some parts of the area, perched water is encountered above the main water table, and the scanty data suggest that at some places there may be more than one perched water table. Nevertheless, by careful study of well logs and hydrologic data, wells were selected in which the water levels were believed to represent the main water table. These water levels were used to construct the water-table map (pl. 1). Although, because of sparseness of the data, the mapmay be inaccurate in some places, it does give a generalized picture of the position and gradient of the water table and the direction of ground-water movement. The apparent slope of the water table ranges from about 200 feet per mile in some places in the southeast corner of the area to less than 50 feet per mile in the northern part. The generally northwesterly slope of the water table is locally modified in four areas:

1. In the southwest corner of the area, the water table is built up by leakage from the Salmon River Canal Co. reservoir.

2. Between Rogerson and the north end of the reservoir, there is a very pronounced trough in the water table which indicates a zone of higher transmissibility extending northward.

3. A high on the water table in an area extending north and northwest from the Rock Creek Hills, between Rogerson and Hollister may be built up by leakage from artesian aquifers, by seepage loss from the main canal of the Salmon River Canal Co., and by infiltration of surface runoff in Deep Creek. At the west edge of this ground-water high, the water table drops off steeply and the contours swing sharply to the south, in a direction toward the contours on the east side of the trough between Rogerson and the reservoir. It is apparent that the trough is somewhat west of this area and extends in a direction slightly west of north.

4. At the north end of the area near the High Line Canal of the Twin Falls Canal Co., the water table has an apparent reversal in slope which may be due to a buildup of the water table from leakage from the High Line Canal and from infiltration of excess irrigation water or it may be due to a perched water table from the same source. However, wells used in defining the water table in this area range to 500 feet in depth, and water levels in the deeper wells are at about the same altitude as in the shallower ones; these facts suggest that the water table mapped is the regional water table. 
Salmon Falls Creek, which forms the western boundary of the area, has cut a deep narrow canyon as much as 400 feet below the general surface of the plain. Except for a reach of about 3 miles at the mouth, shown on the Thousand Springs quadrangle map, the altitude of the canyon bottom is known only at three points. At the foot of the Salmon River Canal Co. dam it is about 4,820 feet. At Roseworth crossing in sec. 19, T. 11 S., R. 14 E., and at Castleford crossing in sec. 20, T. $10 \mathrm{~S}$., R. 13 E., there are U.S.G.S. bench marks at 3,672 and at 3,429 feet altitudes. Although there are nowells to define the altitude of the water table near the canyon rim, it is apparent that the canyon floor is considerably below the level of the water table where it has been defined 5 to 10 miles to the east. Thus it would be expected that Salmon Falls Creek would serve as a major ground-water drain in the area. That it does not is shown by the following discharge measurements made on Salmon Falls Creek at the U.S.G.S. gage, 2 miles downstream from the Salmon River Canal Co. dam, and at Roseworth crossing:

\begin{tabular}{c|c|c|c}
\hline Date & $\begin{array}{c}\text { USGS } \\
\text { gage }\end{array}$ & $\begin{array}{c}\text { Roseworth } \\
\text { crossing }\end{array}$ & $\begin{array}{c}\text { Difference } \\
\text { (gain) }\end{array}$ \\
\hline Sept. 1953_- & 9.60 & 11.3 & 1.7 \\
Feb. 1954_- & 8.60 & 13.7 & 5.1 \\
Jan. 1955_- & 5.89 & 6.70 & .81 \\
Mar. 1955_- & 6.66 & 8.19 & 1.53 \\
June 1955_- & 8.86 & 9.57 & .71 \\
Sept. 1957_- & 11.0 & 11.5 & .5 \\
\hline
\end{tabular}

The discharge measurements in the table above indicate that very little ground water is discharged into the creek from the Salmon Falls area between the Salmon River Canal Co. dam and the Roseworth crossing. Although a small amount of ground water may leave the area as underflow in the Salmon Falls Creek Canyon and another small amount may contribute to the flow of Salmon Falls Creek, it is apparent that most of the ground water leaves the area by some route other than the canyon of Salmon Falls Creek.

There are two possible routes for groundwater flow through and out of the Salmon Falls area other than by way of Salmon Falls Creek. These are (a) northwestward beneath the canyon of Salmon Falls Creek, or (b) northward, generally parallel to, and east of Salmon Falls Creek canyon.
For several miles upstream from the Roseworth crossing, basalt extends to the bottom of the canyon. It is not known whether this basalt is part of the younger, more permeable Snake River basalt, or whether it is older, less permeable basalt, correlative with the Banbury basalt. Thus the basalt may serve as a conduit beneath the canyon in this reach. However, silicic volcanic rocks, and sedimentary strata of the Idaho and Payette formations, crop out in a broad belt extending many miles south and west from the vicinity of Castleford crossing. The position of these rocks is such that any postulated conduit which might cross beneath the canyon upstream from Roseworth.would have to recross or return to the canyon upstream from Castleford crossing. Examination of this reach of the canyon discloses that although there is a large gain in streamflow in the reach, all or nearly all is from irrigation of the Twin Falls tract on the east side of the canyon. Furthermore, the scanty data available from wells on the west side of the canyon indicate that the water table is higher than the floor of the canyon throughout the reach upstream from Castleford crossing. Thus it appears unlikely that ground water moves westward or northwestward beneath Salmon Falls Creek canyon.

It is concluded, therefore, that underflow from the Salmon Falls area moves in a direction somewhat west of north, a few miles east of Salmon Falls Creek, and discharges either into Salmon Falls Creek downstream from Roseworth crossing or into the Snake River, or into both. It seems likely that most of the ground water beneath the Salmon Falls area is prevented from discharging into the nearby parallel canyon by some barrier. The nature of this postulated barrier is not known, but there is evidence to suggest that faulting and canyon filling may be the explanation. Many topographic and drainage features are alined in a northwesterly direction. Some or most of these features appear to be fault traces which aline with faults shown farther north on the geologic map of the State (Ross and Forrester, 1947). The courses of Salmon Falls and Deep Creeks probably were determined, at least in part, by such faults.

There also is evidence of former canyons, now filled or partly filled, that must have led northward to the Snake River. These canyons were cut in older, less permieable rocks and 
were filled with the younger, more permeable basalt flows. Stearns $(1935$, p. 85) described two such canyons now partly exposed in the present Salmon Falls Creek canyon. The troughlike shape of the water table (pl. 1) west of Rogerson and Hollister suggests flow in some sort of permeable channel. Whether this is a filled canyon, and if so, whether it was cut by an ancestral Salmon Falls Creek or Deep Creek are not known, nor is the course of the possible conduit known. However, if the mounds on the water table shown in the vicinity of the High Line Canal represent the regional water table, than one possible location would be nor thwestward roughly parallel to Salmon Falls Creek and 4 or 5 miles to the east. Another possible location would be west of the Twin Falls Municipal Airport, and would leave the area near the corner of Ts. 10 and 11 S. and Rs. 16 and 17 E.

\section{DEVELOPMENT AND UTILIZATION}

Ground water in the area is used for domestic and stock purposes, and for supplemental irrigation. Although ground water has not been used extensively for irrigation, the major part of all ground-water withdrawals probably is used for irrigation.

Approximately 2,000 acre-feet of ground water was pumped in 1957 from 6 irrigation wells, according to reported yields and length of pumping season. Two of the most productive irrigation wells in the area are $14 \mathrm{~S}-15 \mathrm{E}-$ $21 \mathrm{db} 1$ and 28aa1. These wells in effect reclaim water that is lost by seepage from the Salmon River Canal Co. reservoir, the only other source being underflow from the south. Prospects are good for some further development of ground water in this part of the area, but the quantity that might be developed is not known.

Another large-producing irrigation well is $11 \mathrm{~S}-16 \mathrm{E}-2 \mathrm{dd} 1$. The availability of water in this part of the area may be due partly to the proximity of the High Line Canal and the project of the Twin Falls Canal Co. It is not known how much ground water is available for possible extension of irrigation development in this part of the area. In 1958, irrigation well $12 \mathrm{~S}-17 \mathrm{E}-18 \mathrm{dd} 2$ reportedly was pumped at a rate of about $2,500 \mathrm{gpm}$ with a drawdown of 45 feet.
The depth to water, both static and pumping, is an important economic consideration in the utilization of a ground-water supply. Extrapolation of the water levels from the water-table map (pl. 1) and comparison with the small scale contour maps available suggest that in a large part of the western half of the area the depth to water is more than 500 feet. In the central part of the area between Hollister and Berger the depths to water in wells range from about 300 to 600 feet. In most of the area where wells are in use, the depths to water are between 100 and 400 feet. In a few places water is found at shallow depth. Depths to water of less than 100 feet occur in most of T. 13 S., R. 16 E., which lies south of Hollister, in the area between Hollister and the Rock Creek Hills where some artesian wells are located, in some of the small valleys in the southeast corner of the area, and locally along the northern edge of the area, near the Twin Falls Canal Company's High Line Canal.

Data from pumping tests of irrigation wells in the Salmon Falls area made by Layne and Bowler Pump Co., Twin Falls, Idaho, are given in table 1. The specific capacities ${ }^{2}$ range from 1.1 to $55 \mathrm{gpm}$ per foot of drawdown; the median is 27 and the arithmetic average is 10 . The specific capacity of even the most productive well in the area is not comparable with those of wells drilled in basalt in the main part of the Snake River Plain where specific capacities generally are in the hundreds and not uncommonly are more than $1,000 \mathrm{gpm}$ per foot of drawdown.

\section{AMOUNT OF RECHARGE}

Ground water in the Salmon Falls area is derived from precipitation on the area, from seepage loss from surface water flowing into the area, and from ground-water underflow from adjacent areas where the water table is higher than that in the Salmon Falls area. In much of the area it is not possible to evaluate all these sources separately. Instead, the amounts contributed by specific areas are estimated.

\footnotetext{
${ }^{2}$ Well logs and records of wells in the Salmon Falls area are given in Fowler (1960).

${ }^{2}$ The specific capacity of a well is the yield, in gallons per minute, per foot of drawdown. Specific capacities usually decrease with the length of time a well is pumped and change with the rate of pumping; therefore a precise comparison of specific capacities would take in to account these two variables.
} 
GROUND WATER

Table 1. -Data from pumping tests of wells in Salinon Falls area

\begin{tabular}{|c|c|c|c|c|c|c|c|}
\hline Well & Owner & $\begin{array}{c}\text { Depth } \\
\text { to } \\
\text { water } \\
\text { (feet) }\end{array}$ & $\begin{array}{c}\text { Dis- } \\
\text { charge } \\
\text { rate } \\
\text { (gpm) }\end{array}$ & $\begin{array}{l}\text { Draw- } \\
\text { down } \\
\text { (feet) }\end{array}$ & $\begin{array}{c}\text { Specific } \\
\text { capacity } \\
\text { (gpm per } \\
\text { foot) }\end{array}$ & $\begin{array}{l}\text { Depth } \\
\text { of } \\
\text { well } \\
\text { (feet) }\end{array}$ & Aquifer \\
\hline $11 \mathrm{~S}-16 \mathrm{E}-2 \mathrm{dd} 1=-$ & O. A. Schnitker- & 290 & 1,360 & 50 & 27 & 500 & $\begin{array}{l}\text { "Soft red rock." } \\
\text { Probably cinders. }\end{array}$ \\
\hline $6 \mathrm{db} 1 \ldots$ & $\begin{array}{l}\text { Edward } \\
\text { Babcock. }\end{array}$ & 305 & 680 & 150 & 4.5 & 975 & Lava, cinders, talc. \\
\hline $11 \mathrm{~S}-17 \mathrm{E}-23 \mathrm{ad} 1 \ldots$ & Harold Nelson_.- & 195 & 756 & 208 & 3.6 & 514 & Sand (old lakebed). \\
\hline $11 \mathrm{~S}-18 \mathrm{E}-32 \mathrm{cc} 1--$ & Oran Butler.... & 49 & 1,350 & 246 & 5.2 & 300 & Gravel. \\
\hline $12 \mathrm{~S}-15 \mathrm{E}-26 \mathrm{aa} 1$ - & Lee Leichliter - & 315 & 450 & 80 & 5.6 & 625 & Sand. \\
\hline $12 \mathrm{~S}-1,6 \mathrm{E}-22 \mathrm{bc} 1--$ & Leonard Peters_ & 169 & 72 & 41 & 1.8 & 395 & Sand in basalt. \\
\hline $22 \mathrm{dd} 1 \ldots$ & J. K. Courtney - & 70 & 75 & 25 & 3.0 & 191 & \\
\hline $36 \mathrm{db} 1 \ldots$ & John Rayl__._... & 0 & -450 & 100 & 4.5 & $\ldots$ & \\
\hline $12 \mathrm{~S}-17 \mathrm{E}-18 \mathrm{dd} 2 \ldots$ & Glenn Nelson.-- & 135 & 2,500 & 45 & 55 & 230 & Basalt. \\
\hline $13 \mathrm{~S}-16 \mathrm{E}-3 \mathrm{bb} 2--$ & $\begin{array}{l}\text { Martin } \\
\text { Knuds on. }\end{array}$ & 87 & 180 & 159 & 1.1 & $-\ldots$ & $\begin{array}{l}\text { Basalt mingled with } \\
\text { red soil. }\end{array}$ \\
\hline $\left.\begin{array}{r}13 \mathrm{~S}-17 \mathrm{E}-6 \mathrm{bc} 1- \\
\text { and } 6 \mathrm{bc} 2--\end{array}\right\}$ & Ora Jones & 4 & $\begin{array}{r}22,700 \\
(1,810\end{array}$ & $\begin{array}{l}50 \\
95\end{array}$ & $\begin{array}{l}27 \\
19)\end{array}$ & 600 & Rock. \\
\hline $14 \mathrm{~S}-15 \mathrm{E}-28 \mathrm{aa} 1--$ & Ralph Schnell & 191 & $\left\{\begin{array}{l}3,380 \\
1,275\end{array}\right.$ & $\begin{array}{l}60 \\
50\end{array}$ & $\left.\begin{array}{l}23 \\
25\end{array}\right\}$ & 455 & Sandstone and cinders. \\
\hline $\begin{array}{r}14 \mathrm{~S}-16 \mathrm{E}-2 \mathrm{ad} 1-- \\
16 \mathrm{ba} 1--\end{array}$ & $\begin{array}{l}\text { A. E. Kunkel } \ldots \\
\text { Harry Nöh }\end{array}$ & $\begin{array}{r}19 \\
215\end{array}$ & $\begin{array}{r}10 \\
270\end{array}$ & $\begin{array}{r}4 \\
85\end{array}$ & $\begin{array}{l}2.5 \\
3.1\end{array}$ & $\begin{array}{r}60 \\
1,210\end{array}$ & Gravel. \\
\hline
\end{tabular}

${ }^{1}$ Reported by George and Harley, drillers.

${ }^{2}$ Combined yield of the two wells.

${ }^{3}$ Different pumping rates during test.

RECHARGE FROM DIRECT PRECIPITATION

The average annual precipitation within the boundary of the area shown on plate 1 , about 200,000 acres, is about 10 inches, or approximately 167,000 acre-feet per year. Part of the precipitation runs off from the land surface and is discharged into the Snake River, some is evaporated or is transpired by plants, and some is retained as soil moisture; the residual is available for groundwater recharge. Blaney and Criddle (1949, p. 9) estimated that it takes about $6 \frac{1}{2}$ inches of precipitation annually to sustain the type of sparse vegetation that is native to the area. Six and one-half inches is about 70 percent of the total annual precipitation; part of the remainder is lost by evaporation from the soil or by sublimation of snow.

A correlation of average annual precipitation and water yields of drainage basins in southeastern Idaho suggests that 10 inches of precipitation would yield an amount of water equivalent to three-fourths of an inch over the area, or about 12,000 acre-feet per year (Mundorff, oral communication, 1959). Water yield is defined as the total of both surface and ground water which moves out of a basin by surface runoff and underflow. The surface drainage is poorly developed and on the basis of recharge-runoff relations in similar areas of the Snake River basin, it is estimated that about one-half of the yield, or roughly 5,000 acre-feet, becomes ground-water recharge.

RECHARGE FROM UPLAND TO THE EAST AND SOUTHEAST

Deep and Desert Creeks and other small ephemeral streams drain the hills to the east and southeast of the Salmon Falls area. The total amount of recharge derived from that source is unknown. However, a considerable amount of recharge to the area from that direction is suggested by the shallow depth to water and by the shape of the water-level contours southeast of Hollister (pl. 1). The average annual precipitation in this bordering area is about $13 \frac{1}{2}$ inches (fig. 3 ): The relation 
of precipitation to water yield (Mundorff, 1959 , oral communication) indicates that this part of the basin should yield about 3 inches of water over the area of about 100 square miles, or a total of 15,000 acre-feet. Because there is little or no through-flowing drainage from the se hills across the Salmon Falls area, all this yield is considered to be ground-water recharge, either from seepage loss from streams or from underflow from the Rock Creek Hills.

\section{RECHARGE FROM RESERVOIR LOSSES}

The reservoir of the Salmon River Canal Co. on Salmon Falls Creek was constructed in 1909 and 1910. Shortly after construction it became apparent that much water was lost through the porous basalt surrounding the reservoir. Attempts were made to reduce these losses by lining the tunnels and by grouting the abutments and other places of possible leakage near the dam. These attempts were only partially successful.

The discharge of Salmon Falls Creek has been measured at a gaging station near San Jacinto, Nev., since 1910. Average discharge for the entire period of record through 1957 was $134 \mathrm{cfs}$ (cubic feet per second) or 97,000 acre-feet per year. The gaging station is about 10 miles upstream from the head of the reservoir and 20 miles upstream from the dam.

The U.S. Soil Conservation Service (Robert Wagner, written communication, 1956) concluded from its analysis of the published stream-flow records for the period October 1938-September 1951 that annual reservoir losses by evaporation and percolation were equivalent to 8,000 acre-feet plus 20 percent of the flow of Salmon Falls Creek at the San Jacinto, Nev., station, plus all the ungaged inflow. The annual average flow of Salmon Falls Creek for the 13-year period considered was 108,000 acre-feet. Only a rough estimate can be made of the contribution from ungaged inflow in that part of the Salmon Falls Creek drainage between the San Jacinto station and the Salmon River Canal Co. dam. The size of the ungaged area (195 square miles), the average precipitation (9.8 inches) estimated from the isohyetal map (fig. 3 ), and the relation of water yield to precipitation previously mentioned indicate that the annual water yield of this part of the basin may be about 10,000 acre-feet, all of which is groundwater recharge either by leakage from the reservoir or by underflow.

Annual evaporation from the reservoir surface was estimated by the Soil Conservation Service by computing the average surface area of the water for each month of the 13-year period and multiplying this average by the estimated evaporation in inches. The average annual evaporation, it was thus estimated, was 7,800 acre-feet and may well be the constant 8,000 acre-feet mentioned in the Soil Conservation Service's formula for computation of total reservoir loss.

Thus, by the formula of the Soil Conservation Service, annual reservoir losses would be computed and distributed as follows:

\section{$\underline{\text { Reservoir Losses } \quad \text { Acre-feet }}$}

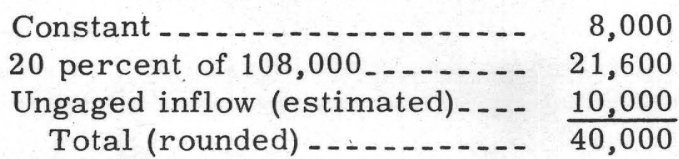

Part of the loss would be accounted for as follows:

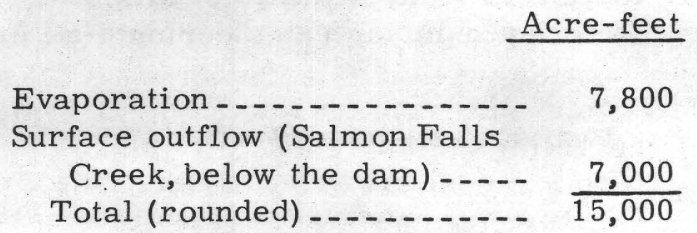

The difference between these amounts, about 25,000 acre-feet, is presumed to be lost by percolation to the water table.

SEEPAGE LOSS FROM CANALS

As a part of their seepage-loss study, the Soil Conservation Service made a study of 138 miles of main canals and laterals in the distribution system. The Soil Conservation Service concluded that seepage losses were excessive, especially in the upper main canal. According to the report, "Company records show that about half of the water diverted into the canals is lost to seepage." Total annual canal diversions, as given in Geological Survey water-supply papers for the 13-year period (1938-51) used by the Soil Conservation Service in the analysis of reservoir losses, ranged from about 36,000 to 106,000 
acre-feet. Average annual diversion during the period was nearly 78,000 acre-feet. Assuming that the water lost by seepage reaches the water table, recharge from this source may have averaged about 40,000 acrefeet per year during the study period.

\section{PERCOLATION FROM IRRIGATION}

Assuming that one-half of the water diverted from the reservoir reached the individual farms, the amount of water that reached the farms during the 1938-51 period may have averaged nearly 40,000 acre-feet. Because this is a water-short area, water is applied sparingly. Nevertheless, some water inevitably escapes by percolation from farm ditches and irrigated fields. It is estimated that about one-fourth of the irrigation water is lost by deep percolation. This loss would represent an average increment to ground water from this source of about 10,000 acrefeet.

\section{POTENTIAL SUPPLY}

The estimated total amount of ground water recharged to aquifers in the Salmon Falls area is shown in table 2. It should be emphasized that, except for losses from the reservoir and from the distribution system of the Salmon River Canal Co., most of the estimates are based on rather tenuous data, and may be considerably in error.

Table 2 is intended only to give an indication of the probable magnitude of the recharge. It should be noted that these computations did not take into account the possibility of ground-water underflow past the San Jacinto gage (fig. 3). Presumably some of the precipitation on the Salmon Falls Creek drainage

Table 2.-Estimated average annual recharge to aquifers in the Salmon Falls area

\begin{tabular}{c|r}
\hline \multicolumn{1}{c|}{ Source } & Recharge \\
\cline { 2 - 2 } & (acre-feet) \\
\hline Direct precipitation.- & 5,000 \\
Upland to east and southeast & 15,000 \\
Reservoir losses & 25,000 \\
Seepage from canals & 40,000 \\
Percolation from irrigation.- & 10,000 \\
Total (rounded) & 100,000 \\
\hline
\end{tabular}

above the gage becomes ground-water underflow and eventually reaches the Salmon Falls area, but the total amount is not known. The relation of precipitation to the expected yield suggests that surface flow past the gage does not account for all the water yield of the basin. The information available from a few scattered wells in the basin indicates that the aquifers are moderately permeable; thus, underflow is possible. However, because no data are available for direct estimates of its magnitude, the underflow from this part of the area was not considered in estimating the total ground water available for recharge in the Salmon Falls area.

Although the estimate of about 100,000 acre-feet of ground-water recharge in the area may be in error, the recharge can hardly be less than the total of reservoir leakage, of seepage loss from canals, and of percolation from irrigated land, which averages about 70,000 acre-feet annually.

Use of the precipitation-water yield relation for the entire basin gives a yield of $2 \frac{1}{2}$ inches over the area of 1,560 square miles above the Salmon River Canal Co. reservoir dam, or an annual basin yield of more than 200,000 acre-feet. The area below the dam would also contribute some water-probably more than enough to supply the few thousand acre-feet of surface runoff. Annual consumptive use by irrigated crops on the Salmon Falls project probably averages about 30,000 acre-feet. Thus this method of estimation, which provides a rough check on the estimates developed in this report, indicates that about 170,000 acre-feet are available for ground-water recharge in the Salmon Falls area. 170,000 acre-feet is probably near the maximum possible amount. The actual amount of water available for groundwater recharge is somewhere between the 70,000 acre-feet minimum and the 170,000 acre-feet maximum; therefore, 100,000 acrefeet seems to be a conservative estimate of the total amount of recharge to, and outflow from, the area.

The preceding estimates were based largely on the period 1938-51, because that was the period for which the Soil Conservation Service analyzed reservoir losses. However, examination of stream discharge and canal diversion records indicates no changes of consequence between 1951 and 1957, and, 
accordingly, the estimates may be considered to represent the water regimen through 1957.

The average specific capacity of irrigation wells in the area for which data were available was found to be $10 \mathrm{gpm}$ per foot of drawdown; this average indicates a moderately low coefficient of transmissibility ${ }^{3}$, which may be roughly 15,000 gpd per foot. The underflow of an aquifer can be computed from the equation $Q=T I W$, where

$Q$ is the quantity of underflow, in gallons per day.

$T$ is the coefficient of transmissibility, in gallons per day per foot.

$\boldsymbol{t}$ is the hydraulic gradient, in feet per mile.

$W$ is the width of the aquifer, in miles.

In a previous section of the report it was shown that no appreciable part of the underflow from the area reached or crossed westward beneath the canyon of Salmon Falls Creek. Therefore, the boundaries of the aquifer are the Rock Creek Hills on the east and some unknown geologic feature east of Salmon Falls Creek on the west. The maximum possible aquifer width in an east-west direction 8 miles north of Hollister is about 20 miles and it may be much less. If $T=15,000, I=50$ feet, and $W=20$ miles in the equation: $Q=15,000 \times 50 \times 20=15$ million gpd or about 17,000 acre-feet per year. This amount is less than 20 percent of the estimated underflow from the area and less than 25 percent of 70,000 acre-feet, which is believed to be the minimum possible underflow. Thus it seems apparent that the coefficient of transmissibility computed from the average specific capacities of irrigation wells in the area is much lower than the actual average coefficient of transmissibility of the aquifer. It seems, therefore, that most of the ground water that leaves the area is moving out through some aquifer or part of an aquifer much more permeable than the parts tapped by most of the existing wells. This conclusion further supports the hypothesis that buried valleys or conduits underlie the area, It may be noted that the average coefficient of transmissibility of the Snake River basalt

\footnotetext{
${ }^{3}$ The coefficient of transmissibility may be defined as the quantity of water (at field temperature) in gallons per day transmitted by the entire thickness of a section of the aquifer 1 mile wide, under a hydraulic gradient of 1 foot per mile.
}

underlying the Snake River Plain on the north side of the Snake River is about 8 million gpd per foot. A conduit only a quarter of a mile wide, having a coefficient of transmissibility of 4 million gpd per foot, would transmit 50 million gpd $(56,000$ acre-feet a year) under a hydraulic gradient of 50 feet per mile.

\section{QUALITY OF WATER}

Chemical analyses of 26 samples of water from the area are shown in table 3. One sample was from the Salmon River Canal Co. reservoir and another was from a spring in sec. 20, T. 14 S., R. $16 \mathrm{E}$. The rest are from wells in the area. All samples were moderately alkaline; $\mathrm{pH}$ values ranged from 7.2 to 8.5 .

Figure 4 shows the classification with respect to the salinity hazard and sodium (alkali) hazard, of the waters sampled for irrigation. The method of assigning the various classes was developed by the U.S. Salinity Laboratory Staff of the Department of Agriculture (1954). It is based on electrical conductivity and the sodium-adsorptionratio. Electrical conductivity is an indication of the mineral content of a water and corresponds roughly to the value for dissolved solids. Waters are divided into four classes on the basis of electrical conductivity: low ( $\mathrm{C} 1$, less than 250 micromhos per $\mathrm{cm}$ ), medium ( $22,250-750$ micromhos per $\mathrm{cm})$, high ( $\mathrm{C} 3,750-2,250$ micromhos per $\mathrm{cm})$, and very high ( $\mathrm{C} 4$, more than 2,250 micromhos per $\mathrm{cm}$ ). The sodium-adsorption-ratio (SAR) is a calculated value based on the sodium, calcium, and magnesium content of the water; it is related to the adsorption of sodium by the soil. It is defined by the equation:

$$
\mathrm{SAR}=\sqrt{\frac{\mathrm{Na}^{+}}{2}}
$$

in which the concentrations are expressed in milliequivalents per liter. By this method of classification, all the samples tested were in the low sodium (alkali) hazard class (S1), but the salinity hazard ranged from class $C 1$ to $\mathrm{C} 4$, or from low to very high. The water from the Salmon River Canal Co. reservoir, from the one spring sampled, and from one 


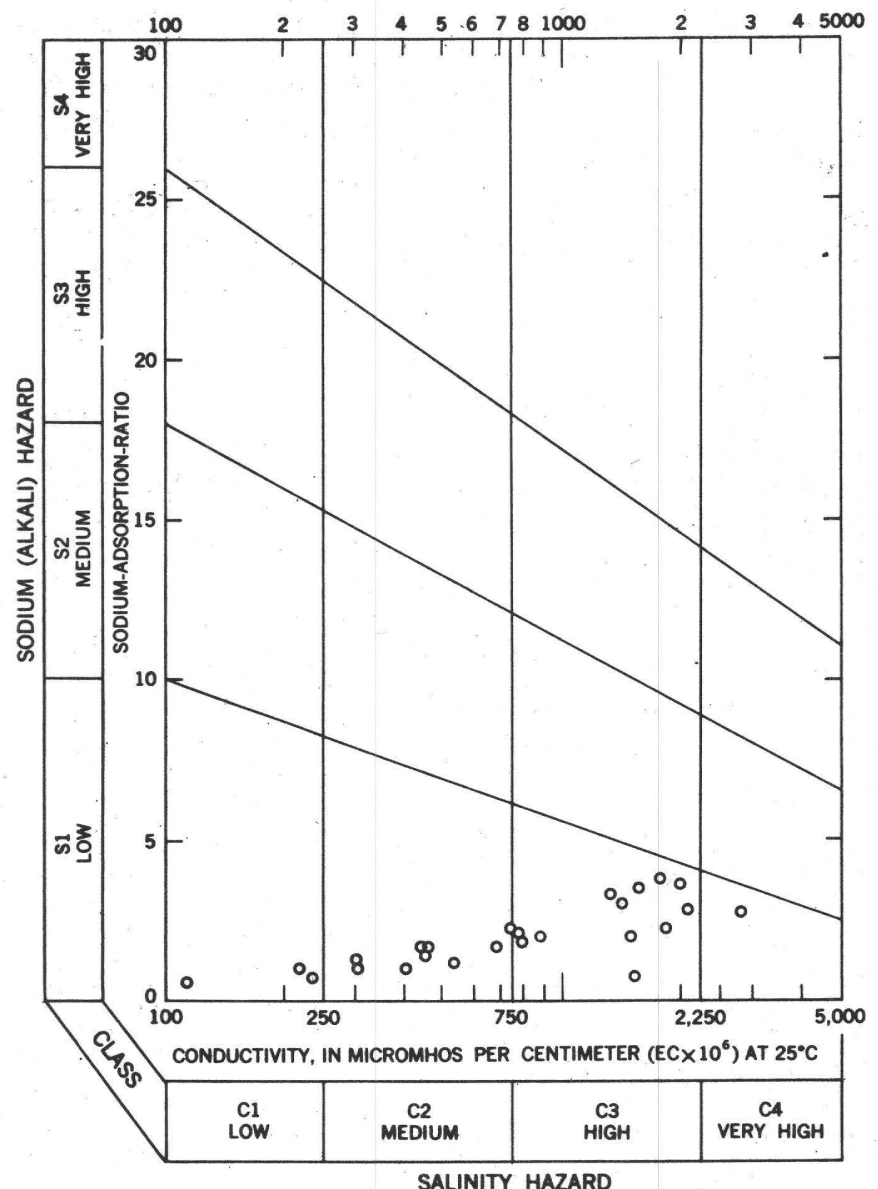

Figure 4. - Classification of water for irrigation, Salmon Falls area, Twin Falls Co., Idaho (after U. S. Salinity Laboratory Staff, 1954).

well (12S-15E-35aa1) were in class C1. Most of the sampies were in classes C2 and C3 and one sample, from well 13S-16E-20aa1 between Hollister and Rogerson, was in class C4.

Water of class S1 can be used for irrigation on almost all soils with little danger of the development of harmful levels of exchangeable sodium. However, certain sodiumsensitive crops may accumulate injurious concentrations of sodium.

The United States Salinity Laboratory has described the significance of the various salinity classes (1954). Low-salinity water (C1) can be used for irrigation of most crops on most soils with little likelihood that a salinity problem will develop.

Medium-salinity water (C2) can be used if a moderate amount of leaching occurs and if it is used on crops with moderate salt tolerance.
High-salinity water (C3) cannot be used on soils with restricted drainage. Even with adequate drainage, special management for salinity control may be required and crops with good salt tolerance should be selected.

Very high salinity water (C4) is not suitable for irrigation under ordinary conditions but may be ussed occassionally under very special circumstances.

Special management practices for use of the high salinity ground water that is common in the area require application in excess of normal irrigation requirements to provide for considerable leaching. The amount of such excess requirements depends on the permeability of the soil and drainage conditions but may range from 25 to 50 percent.

Residual sodium carbonate (RSC) is determined by the equation:

$$
\mathrm{RSC}=\left(\mathrm{HCO}_{3}^{-}+\mathrm{CO}_{3}^{-}\right)-\left(\mathrm{Ca}^{++}+\mathrm{Mg}^{++}\right) \text {. }
$$


Table 3.-Chemical analyses of water in

[Analyses by U.S. Bureau of Reclamation and U.S. Geolog-

\begin{tabular}{|c|c|c|c|c|c|c|c|c|c|}
\hline Well number & $\begin{array}{l}\text { Date of } \\
\text { collection }\end{array}$ & $\begin{array}{l}\text { Tem- } \\
\text { pera- } \\
\text { ture } \\
\left({ }^{\circ} \mathrm{F}\right)\end{array}$ & $\begin{array}{l}\text { Cal- } \\
\text { cium } \\
\text { (Ca) }\end{array}$ & $\begin{array}{l}\text { Mag- } \\
\text { ne- } \\
\text { sium } \\
(\mathrm{Mg})\end{array}$ & $\begin{array}{c}\text { So- } \\
\text { dium } \\
(\mathrm{Na})\end{array}$ & $\begin{array}{l}\text { Po- } \\
\text { tas- } \\
\text { sium } \\
(\mathrm{K})\end{array}$ & $\begin{array}{c}\mathrm{Bi}- \\
\text { car- } \\
\text { bon- } \\
\text { ate } \\
\left(\mathrm{HCO}_{3}\right)\end{array}$ & $\begin{array}{l}\text { Car- } \\
\text { bon- } \\
\text { ate } \\
\left(\mathrm{CO}_{3}\right)\end{array}$ & $\begin{array}{c}\text { Sul- } \\
\text { fate } \\
\left(\mathrm{SO}_{4}\right)\end{array}$ \\
\hline $11 \mathrm{~S}-16 \mathrm{E}-23 \mathrm{ab} 1 \ldots$ & $1-18-57$ & 58 & 126 & 48 & 126 & 39 & 410 & 14 & 206 \\
\hline $11 \mathrm{~S}-17 \mathrm{E}-9 \mathrm{~cd} 1 \ldots$ & $8-31-56$ & 62 & 74 & 92 & 213 & 10 & 328 & -- & 458 \\
\hline $16 \mathrm{ba} 1 \ldots$ & $1-18-57$ & 70 & 34 & 33 & 78 & 3.9 & 136 & 0 & 135 \\
\hline $23 \operatorname{cc} 1 \ldots$ & $1-18-57$ & 58 & 113 & 94 & 182 & 11 & 320 & 6 & 466 \\
\hline $23 \mathrm{dc} 1 \ldots$ & $1-18-57$ & 58 & 48 & 11 & 38 & 9.4 & 123 & 0 & 72 \\
\hline $25 b b 1 \ldots$ & $1-18-57$ & 64 & 132 & 51 & 111 & 12 & 196 & 0 & 320 \\
\hline 28aa1_.. & $1-18-57$ & 60 & 54 & 28 & 70 & 6.3 & 121 & 0 & 104 \\
\hline $12 \mathrm{~S}-15 \mathrm{E}-26 \mathrm{aa} 1 \ldots$ & $1-18-57$ & 58 & 25 & 10 & 25 & 5.5 & 144 & 5 & 12 \\
\hline 35 aa1 $\ldots$ & $1-18-57$ & 58 & 16 & 7.5 & 21 & 3.1 & 109 & 5 & 7 \\
\hline $12 \mathrm{~S}-16 \mathrm{E}-34 \mathrm{bcc} 1 \ldots$ & $1-18-57$ & 59 & 61. & 75 & 157 & 2.0 & 311 & 0 & 260 \\
\hline $36 \mathrm{bb} 1 \ldots$ & $1-18-57$ & 56 & 85 & 31 & 166 & 21 & 340 & 6 & 238 \\
\hline $12 \mathrm{~S}-17 \mathrm{E}-18 \mathrm{cc} 1--$ & $1-18-57$ & 54 & 135 & 42 & 107 & 13 & 323 & 0 & 167 \\
\hline $31 \mathrm{ba} 1^{\mathrm{t}} \ldots$ & $8-31-56$ & 99 & 33 & 14 & 41 & 10 & 270 & -- & 16 \\
\hline $13 \mathrm{~S}-15 \mathrm{E}-1 \mathrm{cc} 1 \ldots$ & $1-18-57$ & 58 & 121 & 50 & 32 & 7.8 & 203 & 0 & 126 \\
\hline $13 \mathrm{~S}-16 \mathrm{E}-1 \mathrm{dc} 1 \ldots$ & $1-18-57$ & 90 & 26 & 16 & 44 & 12 & 251 & 2 & 16 \\
\hline 7 aa1_... & $1-18-57$ & 58 & 50 & 25 & 58 & 3.1 & 294 & 2 & 43 \\
\hline $9 \mathrm{bb} 1 \ldots$ & $1-18-57$ & 54 & 92 & 55 & 179 & .8 & 383 & 0 & 299 \\
\hline $9 \mathrm{dc} 1 \ldots$ & $1-18-57$ & 54 & 157 & 76 & 173 & 3.9 & 288 & 0 & 406 \\
\hline $10 \mathrm{ba} 1 \ldots$ & $1-18-57$ & 56 & 134 & 88 & 143 & 6.2 & 331 & 0 & 358 \\
\hline $12 \mathrm{ab} 1 \ldots$ & $1-18-57$ & 98 & 31 & 12 & 45 & 12 & 257 & 0 & 14 \\
\hline $20 a a 1 \ldots$ & $1-18-57$ & 54 & 210 & 137 & 220 & 5.5 & 329 & 0 & 720 \\
\hline $28 a a 1 \ldots$ & $1-18-57$ & 52 & 22 & 62 & 82 & 5.1 & 365 & 7 & 77 \\
\hline $14 \mathrm{~S}-15 \mathrm{E}-14 \mathrm{aa} 1 \ldots$ & $1-18-57$ & 58 & 34 & 9.6 & 27 & 7.8 & 130 & 0 & 30 \\
\hline $14 \mathrm{~S}-17 \mathrm{E}-5 \mathrm{ba} 1 \ldots$ & $1-18-57$ & 52 & 22 & 7.1 & 28 & 6.3 & 148 & 0 & 10 \\
\hline $\begin{array}{l}\text { Spring in sec. } 20 \\
\text { T. } 14 \text { S., R. } 16 \text { E. }\end{array}$ & $1-18-57$ & 54 & 9.0 & 3.2 & 8.5 & 1.6 & 41 & 0 & 8 \\
\hline $\begin{array}{l}\text { Salmon River } \\
\text { Canal Co. } \\
\text { Reservoir. }\end{array}$ & $1-18-57$ & & 23 & 5.6 & 16 & 5.4 & 111 & 4 & 11 \\
\hline
\end{tabular}

${ }^{1}$ Drilled well at Nah-Supah Hot Springs. 
Salmon Falls area, Twin Falls County, Idaho

ical Survey. Chemical constituents in parts per million]

\begin{tabular}{|c|c|c|c|c|c|c|c|c|c|}
\hline $\begin{array}{c}\text { Chlo- } \\
\text { ride } \\
(\mathrm{Cl})\end{array}$ & $\begin{array}{l}\text { Fluo- } \\
\text { ride } \\
(\mathrm{F})\end{array}$ & $\begin{array}{c}\mathrm{Ni}- \\
\text { trate } \\
\left(\mathrm{NO}_{3}\right)\end{array}$ & $\begin{array}{l}\text { Bo- } \\
\text { ron } \\
\text { (B) }\end{array}$ & $\begin{array}{c}\text { Hardness } \\
\text { as } \\
\mathrm{CaCO}_{3}\end{array}$ & $\begin{array}{l}\text { Sodium } \\
\text { adsorp- } \\
\text { tion } \\
\text { ratio } \\
\text { (SAR) }\end{array}$ & $\begin{array}{c}\text { Residual } \\
\text { sodium } \\
\text { car- } \\
\text { bon- } \\
\text { ate } \\
\text { (meq per 1) }\end{array}$ & $\begin{array}{l}\text { Specific } \\
\text { conduct- } \\
\text { ance } \\
\text { (micro- } \\
\text { mhos at } \\
25^{\circ} \mathrm{C} \text { ) }\end{array}$ & $\mathrm{pH}$ & Class \\
\hline 134 & $-\ldots$ & 52 & 0.28 & 513 & 0.8 & 0 & 1,500 & 8.3 & $\mathrm{C} 3, \mathrm{~S} 1$ \\
\hline 190 & 0.2 & 34 & $\ldots$ & 566 & 3.9 & $\ldots$ & 1,780 & 8.0 & $\mathrm{C} 3, \mathrm{~S} 1$ \\
\hline 70 & $-\cdots$ & 6.8 & .16 & 221 & 2.3 & 0 & 740 & 8.1 & $\mathrm{C} 2, \mathrm{~S} 1$ \\
\hline 226 & $\ldots \ldots$ & 15 & .30 & 666 & 3.1 & 0 & 1,970 & 8.1 & $\mathrm{C} 3, \mathrm{~S} 1$ \\
\hline 50 & $\ldots-\ldots$ & 6.8 & .00 & 166 & 1.3 & 0 & 538 & 8.0 & $\mathrm{C} 2, \mathrm{~S} 1$ \\
\hline 182 & $\ldots \ldots$ & 16 & .14 & 538 & 2.1 & 0 & 1,490 & 8.1 & $\mathrm{C} 3, \mathrm{~S} 1$ \\
\hline 113 & $\ldots \ldots$ & 14 & .14 & 248 & 1.9 & 0 & 793 & 8.0 & $\mathrm{C} 3, \mathrm{~S} 1$ \\
\hline 9 & $\ldots \ldots$ & 5.0 & .13 & 103 & 1.1 & +.45 & 301 & 8.4 & $\mathrm{C} 2, \mathrm{~S} 1$ \\
\hline 6 &,---1 & 1.9 & .20 & 70 & 1.1 & +.52 & 218 & 8.4 & $\mathrm{C} 1, \mathrm{~S} 1$ \\
\hline 162 & $-\cdots-1$ & 25 & .47 & 462 & 3.2 & 0 & 1,460 & 8.1 & $\mathrm{C} 3, \mathrm{~S} 1$ \\
\hline 133 & $\ldots \ldots$ & 6.8 & .30 & 340 & 3.9 & 0 & 1,410 & 8.2 & $\mathrm{C} 3, \mathrm{~S} 1$ \\
\hline 168 & 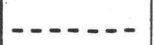 & 57 & .16 & 514 & 2.0 & 0 & 1,480 & 7.7 & $\mathrm{C} 3, \mathrm{~S} 1$ \\
\hline 6 & 1.9 & .1 & $\ldots$ & 140 & 1.5 & 1.6 & 456 & 7.7 & $\mathrm{C} 2, \mathrm{~S} 1$ \\
\hline 158 & $-\ldots \ldots$ & 27 & .28 & 508 & .6 & 0 & 1,230 & 8.1 & $\mathrm{C} 2, \mathrm{~S} 1$ \\
\hline 3 & $\ldots$ & 1.2 & .10 & 128 & 1.7 & +1.6 & .448 & 8.3 & C2, S1 \\
\hline$\cdot 31$ & $\ldots \ldots$ & 31 & .23 & 227 & 1.7 & +.35 & 681 & 8.3 & $\mathrm{C} 2, \mathrm{~S} 1$ \\
\hline 137 & $\ldots \ldots$ & 11 & .77 & 458 & 3.6 & 0 & 1,550 & 8.1 & $\mathrm{C} 3, \mathrm{~S} 1$ \\
\hline 281 & $\ldots \ldots$ & 27 & .20 & 703 & 2.8 & 0 & $2,07.0$ & 8.1 & $\mathrm{C} 3, \mathrm{~S} 1$ \\
\hline 221 & $\ldots \ldots$ & 145 & .24 & 698 & 2.4 & 0 & 1,800 & 8.1 & $\mathrm{C} 3, \mathrm{~S} 1$ \\
\hline 6 & $\ldots \ldots$ & 1.2 & .20 & 126 & 1.8 & +1.7 & 463 & 7.6 & $\mathrm{C} 2, \mathrm{~S} 1$ \\
\hline 354 & -...... & 227 & .67 & 1,130 & 2.9 & 0 & 2,820 & 8.1 & $\mathrm{C} 4, \mathrm{~S} 1$ \\
\hline 46 & $\ldots$ & 12 & .18 & 310 & 2.0 & +.01 & 879 & 8.5 & $\mathrm{C} 3, \mathrm{~S} 1$ \\
\hline 32 & $\ldots \ldots \ldots$ & 3.7 & .17 & 126 & 1.0 & 0 & 405 & 7.7 & $\mathrm{C} 2, \mathrm{~S} 1$ \\
\hline 11 & $\ldots \ldots$ & 1.2 & .07 & 83 & 1.3 & +.76 & 304 & 7.4 & $\mathrm{C} 2, \mathrm{~S} 1$ \\
\hline 5 & $-\cdots-1$ & 3.7 & .17 & 36 & .6 & 0 & 116 & 7.2 & $\mathrm{C} 1, \mathrm{~S} 1$ \\
\hline . 5 & $-\cdots-\ldots$ & 1,2 & .09 & 80 & .8 & +.34 & 237 & 8.2 & $\mathrm{C} 1, \mathrm{~S} 1$ \\
\hline
\end{tabular}


U.S. Salinity Laboratory Staff (1954, p. 81) state: "Water with more than 2.5 meq per 1 (milliequivalents per liter) residual sodium carbonate is not suitable for irrigation purposes. Water containing 1.25 to $2.8 \mathrm{meq}$ per 1 is marginal and water containing less than 1.25 meq per 1 is probably safe." According to this criteria, water from the artesian aquifer southeast of Hollister (wells $13 \mathrm{~S}-16 \mathrm{E}-$ $1 \mathrm{dc} 1,12 \mathrm{ab} 1$ and $12 \mathrm{~S}-17 \mathrm{E}-31)$ might cause some soils to become alkali if used for irrigation.

Wells $13 \mathrm{~S}-16 \mathrm{E}-9 \mathrm{bb} 1$ and $20 \mathrm{aa} 1$, which are in the area of comparatively shallow ground water south of Hollister, contain too much boron ( 0.30 to $0.77 \mathrm{ppm})$ to be suitable for irrigation of crops that are sensitive to boron, but use of their water would have no adverse effect on crops normally grown in this area.

The excessively high nitrate content in samples from wells 11S-16 E-23ab1, 11S-17E$9 \mathrm{~cd} 1,12 \mathrm{~S}-16 \mathrm{E}-34 \mathrm{bc} 1,12 \mathrm{~S}-17 \mathrm{E}-18 \mathrm{cc} 1,13 \mathrm{~S}-$ $15 \mathrm{E}-1 \mathrm{cc} 1,13 \mathrm{~S}-16 \mathrm{E}-7 \mathrm{aa} 1,9 \mathrm{dc} 1,10 \mathrm{ba} 1$ and 20 aa1 may indicate contamination from organic materials. Such contamination would probably present no particular hazard if the water were used only for irrigation but such water does not meet standards of the U.S. Public Health Service for drinking water.

Water containing less than $60 \mathrm{ppm}$ (parts per million) of hardness as calcium carbonate $\left(\mathrm{CaCO}_{3}\right)$ generally is considered soft. Only one of the 26 samples analyzed could be considered soft and 15 of the samples, containing from 221 to $1,127 \mathrm{ppm}$, would be considered very hard. Excessive hardness is especially objectionable for some domestic and industrial uses. Calcium and magnesium carbonate and silica form scale in boilers, hot water heaters, and water pipes.

\section{CONCLUSIONS}

The annual ground-water outflow from the Salmon Falls area may be about 100,000 acre-feet; it probably is not less than 70,000 acre-feet and almost certainly does not exceed 160,000 acre-feet.

Apparently Salmon Falls Creek, the deepest drainage-way in the area, does not serve as a surface drain for ground water leaving the area. If the ground-water mounds shown in the vicinity of the High Line Canal on plate 1 represent the regional water table and not a perched table, then most of the ground-water discharge must be through channels or conduits of limited width. If so, it seems likely that these channels may be ancient buried valleys which were cut in older, less permeable volcanic rocks and lake beds and were subsequently filled with flows of Snake River basalt. One such buried valley was described by Stearns (1938, p. 85). The locations of the assumed buried valleys that are believed to serve as conduits for ground-water outflow from the Salmon Falls area are not known, but the water-table map suggests that one may extend northwest roughly parallel to Salmon Falls Creek, a few miles east of the creek.

Estimates of the transmissibility of the aquifers in the Salmon Falls area, based on specific-capacity data, indicate that the average transmissibility of the aquifers represented by these well tests is much too low to explain all the estimated underflow. This data supports the assumption that there are highly permeable buried conduits that convey a large part of the underflow.

The maximum amount of underflow that might be salvaged through wells is not known, but it may range from 20 to 50 percent of total underflow from the area, and probably is at least 25,000 acre-feet per year. Whether the pumping lifts would be within economically feasible limits is not known.

Further investigations are needed to determine more accurately the quantity of ground water moving through the area and the conditions under which ground water occurs. The location of the postulated buried valleys might be determined by a detailed geologic study and by test drilling. Establishing more precipitation gages and measuring the surface runoff from the hills to the south and east of the area would help to determine the amount of water available for recharge by underflow. The investigations should also include the drilling of several wells suitable for conducting pumping tests with observation wells situated so that resultant drawdown of the water table could be observed. Such an investigation would make possible a better definition of the shape of the water table and of the direction of movement of ground water. It could also provide data from which hydraulic properties of the aquifer 
might be determined, and more detailed quantitative studies then could be made.

\section{REFERENCES}

Blaney, H. F., and Criddle, W. D., 1949, Consumptive use of water in the irrigated areas of the upper Colorado River basin: U.S. Dept. Agriculture, Soil Conserv. Service-Research, 49 p.

Fowler, K. H., 1960, Basic data to accompany report "Preliminary report on ground water in the Salmon Falls area, Twin Falls County, Idaho, U.S. Geological Survey Circular 346": U.S. Geol. Survey open-file report, Boise, Idaho, $57 \mathrm{p}$.

Ross, C. P., and Forrester, J. D., 1947, Geologic map of the State of Idaho: U.S. Geol. Survey and Idaho Bur. Mines and Geology. Stearns, H. T., Crandall, Lynn, and Steward, W. D., 1938, Geology and ground-water resources of the Snake River Plain in southeastern Idaho: U.S. Geol. Survey Water-Supply Paper 774.

U.S. Corps of Engineers, 1952, Columbia River and tributaries, review report: U.S. 81st Congress, 2d sess., House Doc. 531. U.S. Salinity Laboratory Staff, 1954, Diagnosis and improvement of alkali soils: U.S. Dept. Agriculture Handb. 60, 160 p. 